\title{
Author Correction: Single molecule localisation microscopy reveals how HIV-1 Gag proteins sense membrane virus assembly sites in living host CD4 T cells
}

Charlotte Floderer ${ }^{1}$, Jean-Baptiste Masson ${ }^{2}$, Elise Boilley ${ }^{1}$, Sonia Georgeault ${ }^{3}$, Peggy Merida ${ }^{1}$ Mohamed El Beheiry ${ }^{4}$, Maxime Dahan ${ }^{4}$, Philippe Roingeard $\mathbb{1 0}^{3}$, Jean-Baptiste Sibarita $\mathbb{1}^{5}$, Cyril Favard $\mathbb{B}^{1}$ \& Delphine Muriaux ${ }^{1}$

Correction to: Scientific Reports https://doi.org/10.1038/s41598-018-34536-y, published online 02 November 2018

Three supplementary videos were omitted from the original version of this Article. This error has been corrected in the HTML version of the Article; the PDF version was correct at time of publication.

(i) Open Access This article is licensed under a Creative Commons Attribution 4.0 International License, which permits use, sharing, adaptation, distribution and reproduction in any medium or format, as long as you give appropriate credit to the original author(s) and the source, provide a link to the Creative Commons license, and indicate if changes were made. The images or other third party material in this article are included in the article's Creative Commons license, unless indicated otherwise in a credit line to the material. If material is not included in the article's Creative Commons license and your intended use is not permitted by statutory regulation or exceeds the permitted use, you will need to obtain permission directly from the copyright holder. To view a copy of this license, visit http://creativecommons.org/licenses/by/4.0/.

(c) The Author(s) 2018

${ }^{1}$ Infectious Disease Research Institute of Montpellier (IRIM), UMR9004 CNRS, University of Montpellier, 1919 route de Mende, 34293, Montpellier, France. '2Decision and Bayesian Computation, UMR 3571 CNRS, Pasteur Institute, Paris, France. ${ }^{3}$ INSERM U966 and IBiSA EM Facility, University of Tours, Tours, France. ${ }^{4}$ Light and Optical Control of Cellular Organization, Curie Institute, UMR, 168 CNRS, Paris, France. ${ }^{5}$ Interdisciplinary Institute for Neuroscience, UMR 5297 CNRS, University of Bordeaux, Bordeaux, France. Charlotte Floderer and Jean-Baptiste Masson contributed equally. Correspondence and requests for materials should be addressed to C. Favard (email: cyril. favard@irim.cnrs.fr) or D.M. (email: delphine.muriaux@irim.cnrs.fr) 